Please do not remove this page

RMIT

UNIVERSITY

\title{
Integration and fragmentation of post compulsory teacher education
}

Moodie, Gavin; Wheelahan, Leesa

https://researchrepository.rmit.edu.au/esploro/outputs/9921861945801341/filesAndLinks?institution=61RMIT_INST\&index=null

Moodie, G., \& Wheelahan, L. (2012). Integration and fragmentation of post compulsory teacher education. Journal of Vocational Education \& Training, 64(3), 317-331.

https://doi.org/10.1080/13636820.2012.691535

Document Version: Accepted Manuscript

Published Version: https://doi.org/10.1080/13636820.2012.691535

Repository homepage: https://researchrepository.rmit.edu.au

(C) 2012 The Vocational Aspect of Education Ltd.

Downloaded On 2023/04/26 19:37:32 +1000

Please do not remove this page 
Thank you for downloading this document from the RMIT Research Repository.

The RMIT Research Repository is an open access database showcasing the research outputs of RMIT University researchers.

RMIT Research Repository: http://researchbank.rmit.edu.au/

\section{Citation:}

Moodie, G and Wheelahan, L 2012, 'Integration and fragmentation of post compulsory teacher education', Journal of Vocational Education \& Training, vol. 64, no. 3, pp. 317-331.

See this record in the RMIT Research Repository at:

http://researchbank.rmit.edu.au/view/rmit:20870

Version: Accepted Manuscript

Copyright Statement: (c) 2012 The Vocational Aspect of Education Ltd.

Link to Published Version:

http://dx.doi.org/10.1080/13636820.2012.691535 
This is an Accepted Manuscript of an article published by Taylor \& Francis Group in Journal of Vocational Education \& Training on 04 Jul 2012, available online at: http://www.tandfonline.com/10.1080/13636820.2012.691535. 


\section{Integration and fragmentation of post compulsory teacher education}

Gavin Moodie ${ }^{\mathrm{a}}$ and Leesa Wheelahan ${ }^{\mathrm{b}}$

${ }^{a}$ RMIT, Melbourne, Australia

${ }^{b}$ LH Martin Institute for Higher Education Leadership and Management, University of Melbourne, Melbourne, Australia

Correspondence: Gavin Moodie, 5/104 Lygon Street, BRUNSWICK EAST, 3057, Australia, Gavin.Moodie@telstra.com 


\section{Integration and fragmentation of post compulsory teacher education}

The boundaries between vocational and academic post compulsory education have been blurred by students combining vocational and academic studies and by students transferring increasingly between the two types of education. Institutions are also blurring the boundaries between the sectors by increasingly offering programs from two and sometimes three sectors. In contrast, teachers seem more entrenched than ever in their own sector. This article reports a project on the preparation of Australian teachers of vocational education. It examines the prospect of integrating the preparation of teachers in post compulsory education to teach in schools, vocational education institutions and higher education institutions. It argues that greater differentiation between different types of vocational teachers and vocational teacher preparation can support the development of a continuum along which it would be possible to establish points of commonality with the preparation of school and higher education teachers.

Keywords: teacher training, teacher development, policy issues, vocational education and training, further education, community colleges

\section{Introduction}

The tension between integrating and separating forms and processes of post compulsory education arises in interesting ways in teacher education. The differences in the students and purposes served by education after the compulsory years require some differences in the way this education is conducted, but to what extent should these differences be institutionalised and to what extent should students and teachers be left to construct for themselves their learning and teaching to serve their distinctive purposes? Even granted a certain segmentation of curriculum, pedagogy and institutions of post compulsory education, should teachers be confined to or straddle those segments? Different countries answer these questions in different ways and each country's answers change over time. 
This article starts by identifying two issues that arose from the authors’ recent project on the quality of teaching in Australian vocational education and training. The first issue is whether the education of tertiary education teachers might reflect or even lead the blurring of the sectoral boundaries in tertiary education. This blurring of the sectoral boundaries is being observed in Australian federal and State governments’ policies on tertiary education, increased student transfer between the sectors and institutions' becoming more vertically integrated in offering both vocational and higher education. However, it has so far not led to an integration or even convergence of the preparation of teachers for each sector. The second issue is whether all vocational teachers should have the same preparation or whether there should be different teacher education for different types or forms of vocational education.

The article then reviews other recent studies of the preparation of vocational teachers in Australia. It discusses what turned out to be the most controversial part of the project: whether it is still appropriate to refer to vocational education 'teachers' or whether one should adopt some critics' preferred terms 'trainer', 'assessor' or 'practitioner'. The article argues that while context is important in all education, it is more important in vocational education than in other forms because vocational education is grounded more heavily in its social context, in this case, preparation for work. This makes vocational teaching particularly complex. The article then considers its main issue: the extent to which vocational teachers and teacher education should be integrated with other forms of teaching and teacher education, and the extent to which vocational teacher education should be further differentiated by institutionalising different roles and therefore different preparation for different aspects of vocational education. The article concludes that there are strong pressures to differentiate vocational teaching and teacher education in Australia. However, by recognising and 
formalising different roles and preparation of vocational teachers one may establish a continuum of roles and preparation of vocational teacher/trainers along which it would be possible to establish points of commonality with the preparation of school and higher education teachers.

\section{Issues}

All countries distinguish to varying extents between education that prepares students directly for work, called vocational education in this article, and education that prepares students for further learning or is less closely associated with work, which we call academic education. Some countries, particularly those in northern continental Europe, distinguish further between initial vocational education that prepares students to enter work and continuing vocational education for students already in work (Misra, 2011, p. 29). This distinction may be reflected in different organisational arrangements, with initial vocational education based mostly at educational institutions and continuing vocational education based mostly at workplaces. This in turn may generate different roles for those teaching vocational education, with teachers of initial vocational education called teachers and teachers of continuing vocational education called trainers (Misra, 2011, p. 31). Some countries such as Germany distinguish further between the parts of initial vocational education that are practical and those that are theoretical and general (Misra, 2011, p. 33). South Africa proposes to establish three categories of teachers of initial vocational education: those who teach general subjects, those who teach vocational disciplines, and those who provide practical instruction in, for example, workshops (Papier, 2010, p. 159).

Australia has long distinguished vocational and academic post compulsory education. Until the 1970s that distinction started at school: academic education was 
provided at high schools, and vocational education was provided at trade schools and then at technical high schools. As participation in post compulsory secondary education increased, State governments in Australia closed technical high schools and made high schools responsible for providing broader senior secondary education, although in practice they offered academic education to a broader range of pupils. From the mid 1970s the distinction between vocational and academic institutions was moved to tertiary institutions. Vocational education was formally recognised as a distinct sector of tertiary education in 1975 with the redesignation and establishment of public providers of vocational education as colleges of Technical and Further Education (TAFE). Over the next 15 years, the education offered by TAFE and other vocational colleges was distinguished increasingly sharply from academic education offered by universities and higher education colleges. The distinctions between vocational and academic tertiary education are starting to blur as participation in all forms of tertiary education increases as Australia moves from mass to universal higher education (Trow, 1974). The Australian Government now plans ‘an interconnected tertiary education sector’ (Commonwealth of Australia, 2009, p. 8) that distinguishes less sharply between if not integrates vocational and academic education. One issue, then, is whether the education of tertiary education teachers might reflect or even lead the blurring of the sectoral boundaries in tertiary education.

A second issue is whether all vocational teachers should have the same preparation or whether there should be different teacher education for different types or forms of vocational education. This is particularly salient for Australia where the vocational education that is subject to public policy is broader than the vocational education overseen by governments in some other countries. Australian governments assume responsibility for vocational education at all stages of a person's career. The 
governments of many continental European countries are concerned with initial vocational education, leaving most continuing vocational education to employers. There is no such formal distinction between initial and continuing vocational education in Australia, as there is not in the United Kingdom and the United States: Practices differ in each State, but most US States and the federal government do not collect statistics on let alone monitor nor seek to regulate vocational education that is funded privately. Hence a big but indeterminate amount of US vocational education is beyond public policy (Osterman, 2011, p. 136). The position is complicated in Australia, but Australian governments collect statistics on all publicly funded vocational education and oversee at least broadly vocational education funded privately at TAFE institutes. Since TAFE institutes provide most vocational education in Australia, Australian State and federal governments oversee most vocational education. They also regulate the vast majority of vocational qualifications recognised by students, employers and government authorities. In contrast, many English vocational qualifications are awarded by one of several private examination boards such as the not for profit City and Guilds and the for profit Edexcel. While certificates awarded by software vendors Cisco Systems and Microsoft Corporation and by car and aircraft manufacturers have some currency in Australian vocational education, they do not seem as prominent as in many other countries.

Several factors are increasing attention to vocational teacher education. Many countries are expecting more of vocational education. Many countries seek to improve their productivity, to which vocational education is understood to contribute importantly. Some countries look to vocational education as much as other education sectors to reduce inequality. Australia's workforce participation is not high and the country hopes to increase it through vocational education (Skills Australia 2011). 
Australian employers still complain about vocational education being insufficiently practical, irrelevant, of poor quality and inflexible (NCVER 2009, p. 14),despite being ‘industry led’ from the 1990s. From 2000 most of Australia’s vocational education has been based on work competences which have been heavily criticised by educators, while the advocates of competence based training have argued that the problems are not with this form of training but with its implementation (Guthrie 2009a). Australian governments have steadily cut funding for vocational education over the last decade. Over the same period governments have used competitive and often market mechanisms to allocate increasing proportions of public funding for vocational education to private for profit providers as well as public institutes (Skills Australia 2011). The cost cutting and marketisation of Australian vocational education has raised concerns about its quality, which have been heightened by several prominent failures of standards and quality (Schofield 1999a, 1999b, 2000).

A high proportion of Australian vocational teachers are employed on casual or sessional contracts, although because of the paucity of data on staff in vocational education it is impossible to know how many. However, probably from half to twothirds of vocational teachers are employed on casual contracts (Guthrie 2010a). As with many other OECD countries, it seems that Australian vocational teachers are ageing and will probably need to be replaced soon (OECD, 2010, p. 92). All of these factors have implications for the preparation of vocational teachers. In addition, governments in the US, UK, Australia and elsewhere have been paying more attention to the preparation and quality of school teachers to try to cut their preparation time and to reintroduce pay for performance (OECD 2011). This attention on the preparation and quality of teachers in the much more prominent school education is probably being applied to vocational education. 


\section{Studies}

In response to these issues several studies of vocational teacher preparation in Australia have been commissioned recently. There has also been extensive criticism of the mandatory teaching qualification in vocational education (Clayton 2009), which is a general low level vocational education certificate called the Certificate IV Training and Education. There have been criticisms of the way the certificate is delivered (Skills Australia 2011, p. 87), and of its lack of attention to pedagogy. Critics argue that the certificate does not provide adequate preparation for vocational teachers, that it does not take into account the different contexts of vocational teaching and that it does not take into account the fact that vocational teachers now also teach senior school and higher education qualifications.

Service Skills Australia, the industry skills council established by the Australian Government to develop and review vocational qualifications in service industries, commissioned an investigation of the development of vocational teachers for the service industries (Smith and others, 2009). The National Centre for Vocational Education Research commissioned a study of vocational teachers' experiences of their teacher preparation (Clayton, 2009) and undertook several studies of vocational teaching and teacher preparation (Guthrie, 2009b, 2010a, 2010b, 2010c; Guthrie, McNaughton, and Gamlin 2011). The Australian Government commissioned a study of the vocational education and training workforce from its advisory body on microeconomic policy and regulation. Skills Australia (2011, p. 90, 97), which advises the Australian Government on the nation's workforce development, made recommendations on vocational education teacher preparation and workforce development in its plan for vocational education. An audit of the vocational teacher training qualification in Western Australia found that half of the providers offering the qualification did not comply with quality 
requirements and that there was a wide range in the duration of the program, from eight days to six months (Training Accreditation Council Western Australia 2010).

This article reports a project on the quality of teaching in Australian vocational education and training commissioned by the Australian Government. The project was conducted in two stages during 2010 and 2011. The first stage included 71 interviews of teachers and senior staff in nine vocational colleges, managers in three industry skills councils, staff of industry peak bodies and key vocational bodies, and of researchers of vocational education. The first stage also included an open ended web survey which was completed by approximately 1,400 people interested in Australian vocational education, most of whom were teachers. The second stage comprised interviews with 32 vocational students, 25 graduates and 17 employers of vocational graduates. The project produced a literature review; an overview of the results of the interviews and web survey; a conceptual framework for evaluating the quality of vocational teaching, teacher preparation and development, and of vocational students' experiences and outcomes; a review of the data available on the quality of vocational teaching; an options paper; and a final report. The reports are available on the web site of the Australian College of Educators (2011) which managed the project (https://austcolled.com.au/announcement/study-quality-teaching-vet).

\section{'Teacher'}

The identity of vocational teachers is controversial in Australia. This is reflected in debates about what to call vocational teachers and teaching. These debates also reflect the tensions between vocational education and the schools and higher education sectors. Some advocates for vocational education seek to reinforce its distinctiveness by seeking to establish vocational teachers and teaching as being of a different type to teachers and 
teaching in the other education sectors. The project's options paper set out several models and proposals for public discussion. It contained this prominently on page four:

\section{Note on terminology}

The term 'teacher' has been used in this report to include:

Teachers

Trainers

Lecturers

Tutors

Assessors

Workplace assessors and/or trainers

VET practitioners

VET workplace consultants

Those who develop courses and modules and learning and assessment materials

Any other term that may be used to describe those present teaching and learning.

(Wheelahan and Moodie 2010, p. 4)

This provoked several passionate responses and was the most controversial part of the project. In every public presentation made by the project's researchers, teachers in TAFE institutes thanked the authors for acknowledging their role as teachers. They said that this restored the value of their role and their sense of worth. In contrast, others were highly critical of the paper’s teacher terminology. The Australian Industry Group, an association of employers, wrote in response to the options paper:

Whilst the terminology statement at the beginning of the Options Paper provides a scope statement, by then utilising the term teaching/teacher as all encompassing continues to reinforce an out-of-date and narrow paradigm.

The industry skills council for agriculture, food processing, meat, seafood and racing responded: 
It is the view of AgriFood Skills Australia, that the Quality of Teaching in VET

Options Paper was compromised by the decision to group all VET teachers, trainers, assessors etc together.

The industry skills council for manufacturing wrote in its submission:

Concern is expressed about the use of the term 'teacher' to define the VET workforce who present teaching and learning. Teaching only represents part of the role of a VET professional and neglects the important role of assessment. (Manufacturing Skills Australia)

Some corporations provide training to their employees that is accredited and often subsidised by the Australian Government. These corporations are relatively evenly divided between small, medium and big enterprises (ERTOA 2009, p. 3). While some include public organisations such as the army, most are private for profit businesses. The enterprise registered training organisation association (ERTOA), which represents these organisations, wrote:

ERTOA has chosen not to respond to the questions posed at the end of the Options Paper, as ERTOA feels that the report is constructed with such a narrow view of the sector, that the questions are not relevant...Even though the Options Paper defines 'Teachers' broadly..., this broad definition is not represented elsewhere in the reports and seems tokenistic at best.

A little later ERTOA wrote that:

Words such as institutions, teachers, students, learners and graduates; and assertions about teachers being:

“.. [The] institutions' most valuable resource and are usually their biggest item of expenditure" emphasise the myopic view.

These views were expressed even though the big majority of vocational students study on campus and most are not employed in the area in which they study (Wheelahan and 
Moodie 2011). The options paper canvassed the possibility of establishing different preparation and qualification requirements for teachers whose main responsibilities are not in teaching (such as workplace supervisors), and this would comprise most teachers in enterprise registered training organisations. However, this reflection of educational and organisational differences amongst vocational teachers clearly was not sufficient. Critics sought a stronger symbolic acknowledgement of their distinctiveness in the language of vocational teacher preparation and development. The final report conceded something to this desire by referring to ‘teachers/trainers' (Wheelahan and Moodie, 2011, p. 5).

\section{Context}

While the education of teachers affects the quality of their teaching, it is not the only factor to do so (Wheelahan and Curtin, 2010, p. 16). The quality of teaching is affected by the extent to which student factors, the teaching context and the nature of the learning activities and outcomes are aligned (Biggs 1999: 18). It is also affected by the nature of the institution, institutional policies and cultures, broader sectoral policies and structures, as well as the broader social, political and economic context (Devlin and Samarawickrema, 2010, p. 118). The quality of teaching is also shaped by the teacher selection processes, appraisal, recognition and reward schemes, and the nature of the leadership of teaching. It is also affected by workplace practices designed to support learning, such as peer review of teaching, mentoring and coaching (National Academy of Education 2009, p. 1; Darling-Hammond 2000, p.1; Harris, Farrell, Bell, Devlin \& James 2008; Billett 2002). Work design and workforce development also affect the quality of teaching (Guthrie and Clayton 2010). Blom and Meyers (2003, p. 45) identify 22 elements of the quality of vocational education and training including the quality of 
teachers, student support, learning environment and student demographics and inclusiveness. Only a few of these are about teacher preparation and development.

Context is important for all sectors of education. It is, however, arguably more important for vocational education because of its close relation with work. This is particularly so in Australia where work is vocational education's dominant if not sole purpose. Schools develop pupils as citizens and for further education. In higher education the liberal arts and sciences develop students' expertise in their discipline and for further education, and applied higher education develops students as professionals and for further education. While school and higher education have vital social roles, these are mediated by stable and well accepted institutions such as school curriculum bodies, certification boards, occupational associations and discipline associations.

Australian vocational education and training has bodies that may play a similar role such as industry skills councils, some fields have occupational associations, and fewer have licensing boards. But these bodies in Australia have not developed a social mediating role as strong as their vocational education analogues in some other countries, and certainly not as strong as their analogues in school and higher education. Furthermore, Australian vocational education has under-developed roles in preparing graduates for a career in their chosen occupation let alone for citizenship through its narrow focus on work competences. Australian vocational education also has an under developed role in preparing students for further education. So Australian vocational institutes, program heads, and particularly teachers have a greater role in mediating the social context of vocational education than they have in school and higher education. Hence the quality of vocational education is subject more than other sectors to external factors such as the needs of work, workplaces’ support for education, and the availability and quality of apprenticeships and other extended work placements. 
Likewise external factors such as graduates' immediate usefulness at work, their employment outcomes and employers' satisfaction, have been more significant indicators of the quality of teaching in vocational education than in other sectors (Moodie, 2010, p. 7).

\section{Differentiation within a comprehensive system}

The project sought to recognise the diversity of teachers' roles within Australia's reasonably comprehensive system of vocational education in two ways: first, by recognising that vocational education in Australia now includes substantial provision in senior school certificates and small but growing provision in higher education. Secondly, the project recognised that there was great diversity within vocational teaching which reflects teachers’ different occupational and industry specialist fields, and the diversity of vocational students and contexts. The authors argued that teaching refugees, long term unemployed and early school leavers with low levels of language, literacy and numeracy is quite different from teaching higher education and higher level vocational qualifications.

The project's report argued that teachers who taught the most disadvantaged students needed to be the most qualified. It argued that the current single generic vocational teaching qualification be replaced by a framework of different qualifications that reflected the diversity of vocational teaching and its diverse occupational fields, contexts, qualification types, and different student groups. A qualifications framework would also contribute to supporting ‘cross-sectoral' teaching and to integrating teaching in post-compulsory education. For example, by proposing that teachers undertake qualifications appropriate to their teaching, those who taught early school leavers would be equipped to teach in schools, while those teaching higher education would be 
equipped to teach in universities and other higher education institutions. Such an approach would contribute to curricular coherence across the sectors and support students’ transitions between sectors.

The qualifications framework proposed by the report identified four roles: visiting experts, workplace trainers and assessors, teachers responsible for teaching and learning within frameworks established by others, and teachers who were also responsible for program development. Visiting experts are teachers who are engaged to teach occasional sessions in their area of expertise but are not expected to provide a coherent course of study. Their main contribution is their experience and expertise in a field of practice rather than a pedagogic form of contextual knowledge and expertise. Workplace trainers and assessors train and assess their organisation's employees as part of their broader role in their organisation, usually as a supervisor. Their main interest is their charges' development as employees, in which their mastery and certification for a vocational qualification is only a part.

Many vocational teachers are responsible for teaching, learning and assessment within frameworks developed and usually supervised by others, but not for designing and developing curriculum and assessment. Other vocational teachers are responsible for teaching and learning and also for curriculum, pedagogic strategies and assessment innovation, design, development and implementation. Australian higher education institutions vary in the extent to which they distinguish between teachers with greater or lesser responsibility, with some having policies that prohibit casual teaching staff from having full teaching roles and responsibilities, Schools do not formally distinguish between teachers who are competent only to teach and assess within a framework developed by others, and teachers who are also competent to design and develop curriculum and assessment. 
However, such a distinction may be useful in Australian vocational education, at least during a development phase, since it does not yet have an established tradition of extensive teacher preparation. Such a distinction would allow one to require full teacher preparation and continuing development only for teachers who are responsible for curriculum and assessment design, development and implementation. While school and higher education do not formally distinguish between teachers with limited and full responsibility, England's further education sector distinguishes between associate teachers and qualified teachers who must 'demonstrate an extensive range of knowledge, understanding and application of curriculum development, curriculum innovation or curriculum delivery strategies (Institute for Learning 2011; Her Majesty’s Stationery Office 2007, sub section 2 (1)). As one of the anonymous reviewers of this manuscript initially submitted to the journal pointed out, English further education's distinction between associate and qualified teachers is based on long established differences in roles in which many associate teachers are responsible only for the practical parts of vocational education. The distinction in Australian vocational education would be somewhat different and would be made in a rather different context, but the arrangements in English further education are useful in establishing a precedent for some vocational teachers being qualified differently for different roles.

The project's report proposed three levels of teacher preparation and development which would be nested or build on each other: induction, an entry qualification, and an advanced qualification. Teachers would be required to undertake qualifications appropriate for each of the four teachers' roles and levels of responsibility. Visiting experts would be required to undertake only an induction program relevant to their role. Workplace trainers and assessors would be required to complete an induction program before they started training and they would be required 
to complete an appropriate level of credentialed training within a specified time after starting training. Teachers who do not have full responsibility for curriculum development would be required to undertake an induction program before starting teaching and an entry level qualification once they begin teaching. Teachers who have full responsibility for curriculum development would be required to undertake an induction program before starting teaching, an entry level qualification once they start teaching, and subsequently an appropriate advanced teaching qualification in their occupational and disciplinary specialisation. The advanced teaching qualifications would also allow specialisation for teachers who teach vocational education to school students and those who teach higher education qualifications. Such qualifications would also reflect the differences between different occupational fields.

Arguably, vocational education's close association with work makes vocational teaching more complicated than academic teaching. Shulman (1986, p. 9) argued that school teachers need three categories of content knowledge: subject matter content knowledge, pedagogical content knowledge or 'the ways of representing and formulating the subject that makes it comprehensible to others', and curricular knowledge or knowledge of the variety of instructional materials available to teach one’s subject. Curricular knowledge has two sub categories: lateral curriculum knowledge (the curriculum that one’s pupils are following in other subjects), and vertical curriculum knowledge (what is taught in proceeding and later years in the discipline). Academic teachers have one main role: to make academic knowledge comprehensible to others, their pupils and students. In contrast, vocational teachers have two main roles. They reformulate vocational knowledge from work where it has mainly a productive function to a teaching-learning function, and they make this recontextualised vocational knowledge comprehensible to others - to students and 
novice practitioners or workers. Moreover, not all vocational pedagogy is of the same type; it is specific to areas of practice and disciplines. As Young (2006, p. 157) wrote ... they [college teachers] will be specialist vocational teachers in their particular area of the vocational curriculum. They will not only be familiar with the content and philosophy of the new curriculum and how it may need to change, but they will also need to be aware of its implications for teaching, learning and assessment. For example, teaching marketing or business administration raises quite different pedagogic and assessment issues than teaching plumbing or electrical installation. It is this specialist pedagogic knowledge that college teachers will need to acquire, either before they join the staff of a college, or on day or block release during their first appointment. (Young 2006, p. 157)

The UK Office for Standards in Education (Ofsted 2003, pp. 20, 36) argued that the national standards for further education should give more attention to subject or occupational pedagogy and that teacher trainees should have more opportunity to develop subject-specific pedagogy. While occupational and subject pedagogy now formally appear in further education teacher requirements, Lucas and Nasta (2010, p. 466) report that a recent study of 20 further education teacher training programs offered by universities found that trainees had no specialist module options. It is not yet clear what subject-occupationally specific vocational pedagogy might be.

The project recommended that fundamental research be undertaken on pedagogies appropriate for vocational education and on pedagogic content knowledge in different occupational fields. This might lead to the development of cooperative networks to research the scholarship of vocational teaching and promote the adoption of appropriate pedagogies.

These proposals are a considerable advance on vocational teacher preparation and development currently in Australia. Improving vocational teacher preparation would require supporting institutions and processes such as a vocational teacher's 
professional association, standards for vocational teaching, and accreditation of teaching qualifications.

While the studies of vocational teaching cited above report that there is a groundswell of support for increasing the qualifications requirements for vocational teachers to reflect the increased demands being made of vocational education, private providers and some State governments strongly resist any increase in the requirements for vocational teacher preparation and accreditation since they infer that this would increase their costs. Three-quarters of Australian vocational education that is funded by governments is offered by public institutes, with much of the balance offered by private providers. Australian governments are seeking to expand the role of private providers to increase competition between providers, and thereby according to government, to increase providers’ responsiveness to employers’ needs and efficiency. In view of private providers' and some State governments’ resistance of higher teacher qualifications, the project recommended that its proposals be implemented in three stages: an augmented status quo, intermediate enhancement, and ambition. The aim was to provide time to build a consensus on vocational teacher qualifications and to marshal the needed resources (Wheelahan and Moodie 2011, p. 22).

\section{Conclusion}

In many countries such as the UK, US, Canada, Australia and Aotearoa New Zealand, students are undertaking studies outside the sector of their main qualification. Thus, senior secondary students are studying first year bachelor subjects in the USA and Canada where they are known as advanced placement subjects and in Australia where they are known as extension studies. While separate vocational tracks have long existed in secondary education, more recently students on the academic track have started 
studying vocational subjects as part of their academic senior secondary certificate, known in Australia as vocational education and training in schools. In many institutions higher education students are able to study vocational subjects as part of their bachelor program, such as bachelor of science students completing a laboratory technician's certificate within their bachelor program. In many countries, although not Australia, students are able to take academic or general subjects as part of their vocational qualification.

English further education colleges, US and Canadian community or two-year colleges, Australian TAFE institutes and Aotearoa New Zealand's institutes of technology and polytechnics are increasingly offering higher education qualifications such as associate, foundation and full bachelor degrees. Universities in at least England and Australia are becoming more vertically integrated by offering pathways programs, vocational programs and senior secondary certificates that lead into their bachelor programs (Moodie 2009, p. 61).

While the sectoral boundaries are being blurred by students and institutions, their blurring by staff is as yet mixed. A high point in Australia is Charles Darwin University, which is a 'dual sector' university in Australia’s Northern Territory, which has half its student load in vocational education and half in higher education. Charles Darwin University (2011) recently adopted a labour agreement that integrates its salary scales for staff who teach mainly in vocational education and those who teach mainly in higher education, and facilitates and encourages staff to teach in both sectors. But this is rare, even amongst dual sector institutions which have substantial load in both vocational and higher education. This is reflected in sharply different preparation programs for teachers in each sector. 
School teachers are prepared by a combination of education in their teaching disciplines and education in pedagogy. This combination may be studied sequentially or concurrently and takes at least four years of equivalent full time study. School teachers are typically tightly regulated and their preparation programs accredited by bodies with State authority. In many countries higher education teachers are not regulated, but there is a general expectation that they have a qualification in the discipline they teach at least one level higher than the level they teach. Higher education teachers are also increasingly expected to have undertaken a program in higher education pedagogy such as the UK's postgraduate certificate in academic practice or the various graduate certificates in university teaching at Australian universities. Vocational teachers are regulated by many jurisdictions, although not in the US and only indirectly in Australia. Where they are regulated, vocational teachers have had very different requirements from school and higher education teachers (Bailey and Robson 2002). Furthermore, the differences in the preparation of school, vocational and higher education teachers have at least until recently been reinforced (Lucas and Nasta 2010, p. 442). Yet it seems incongruous that while staff may be expected to teach outside their disciplinary specialisation within the same sector, they are inhibited in teaching their discipline in another sector. The 'mismatch' in education for 14 to 19 year olds in the UK led the UK’s Skills Commission (2010, pp. 9, 27) to write -

The key conclusion of this inquiry is the need to converge the two separate teacher training regimes that currently exist for teachers of academic subjects in schools and those of vocational subjects in further education and the post-compulsory sector. The two regimes should be replaced by a unified training system and a ‘universal teaching status’. (Skills Commission 2010, p. 9)

While the UK Government did not follow that advice, it accepted the Wolf report's (2011, p. 127) recommendation 'to allow qualified further education lecturers to teach 
in school classrooms on the same basis as qualified school teachers' (Department for Education, 2011).

The project reported here found little support for aligning the preparation of vocational teachers with the preparation of either school or higher education teachers. However, by recognising and formalising different roles and preparation of vocational teachers/trainers one may establish a continuum of roles and preparation. Such a continuum may include teaching school and higher education qualifications as well as vocational qualifications. It may also recognise vocational teachers’ different occupational and disciplinary specialist areas. Experts who give occasional classes may be given a brief induction but arguably do not need more teacher training. People who train and assess workers as a subsidiary role in the workplace may be inducted and prepared for their role without a full teacher preparation. Teachers responsible for teaching-learning and assessment within frameworks developed by others need full preparation for their role, but this may be less than the preparation of teachers who are also responsible for designing curriculum, pedagogy and assessment. Along that continuum it would be possible to establish points of commonality with the preparation of school and higher education teachers.

\section{Acknowledgement}

We thank the journal's two anonymous reviewers for their constructive comments on the manuscript initially submitted to the journal, all of which we have sought to incorporate in the published article. 


\section{References}

Australian College of Educators. 2011. Final report and recommendations on the quality of teaching in VET. Australian College of Educators.

https://austcolled.com.au/announcement/study-quality-teaching-vet.

Bailey, B. and J. Robson. 2002. Changing teachers: a critical review of recent policies affecting the professional training and qualifications of teachers in schools, colleges and universities in England, Journal of Vocational Education \& Training. 54, no. 3: 325342.

Biggs, J. 1999. Teaching for quality learning at university. Buckingham: SRHE \& Open University Press.

Billett, S. 2002. Towards a workplace pedagogy: guidance, participation, and engagement. Adult Education Quarterly 53, no. 1: 27-43.

Blom, K. and D. Meyers. 2003. Quality indicators in vocational education and training: international perspectives. National Centre for Vocational Education Research. http://www.ncver.edu.au/publications/1383.html.

Charles Darwin University. 2011. Charles Darwin University and union enterprise agreement. Darwin: Charles Darwin University, mimeo.

Clayton, B. 2009. Practitioner experiences and expectations with the Certificate IV in Training and Assessment (TAA40104): a discussion of the issues. National Centre for Vocational Education Research. http://www.ncver.edu.au/publications/2183.html.

Commonwealth of Australia. 2009. Transforming Australia's higher education system. Commonwealth of Australia.

http://home.deewr.gov.au/Budget/documents/TransformingAusHigherED.pdf.

Darling-Hammond, L. 2000. Teacher quality and student achievement: a review of state policy evidence. Education Policy Analysis Archives 8, no. 1: 1-44.

http://epaa.asu.edu/ojs/article/viewFile/392/515.

Devlin, M. and G. Samarawickrema. 2010. The criteria of effective teaching in a changing higher education context. Higher Education Research \& Development 29, no. 2: 111-124.

Enterprise Registered Training Organisation Association 2009, Profiling the Australian Enterprise RTO: A DEEWR-funded project managed by the Enterprise RTO Association October 2009 Summary Report, ERTOA, Canberra, http://www.ertoa.org.au/library/Final_profile_report_for_members_V3.pdf

Guthrie, H. 2009a, Competence and competency based training: what the literature says, National Centre for Vocational Education Research, Adelaide, http://www.ncver.edu.au/publications/2153.html.

Guthrie, H. 2009. How are VET teachers receiving their initial training?. National 
Centre for Vocational Education Research.

http://www.ncver.edu.au/workinprogress/projects/10433.html.

Department for Education. 2011. Wolf Review proposes major reform of vocational education. Press notice 3 March, updated 17 November.

http://www.education.gov.uk/inthenews/inthenews/a0075181/wolf-review-proposesmajor-reform-of-vocational-education

Guthrie, H. 2010a. Vocational education and training workforce data 2008: A compendium. National Centre for Vocational Education Research. http://www.ncver.edu.au/publications/2218.html.

Guthrie, H. 2010b. Professional development in the vocational education and training workforce. National Centre for Vocational Education Research. http://www.ncver.edu.au/publications/2279.html.

Guthrie, H. 2010c. A short history of initial teacher training. National Centre for Vocational Education Research. http://www.ncver.edu.au/publications/2311.html.

Guthrie, H. and B. Clayton, Berwyn .2010. Building capability in vocational education and training providers: the TAFE cut. National Centre for Vocational Education Research. http://www.ncver.edu.au/publications/2224.html.

Guthrie, H., A. McNaughton and T. Gamlin. 2011. Initial training for VET teachers: a portrait within a larger canvas. National Centre for Vocational Education Research. http://www.ncver.edu.au/publications/2390.html.

Harris, K., K. Farrell, M. Bell, Maureen, M. Devlin and R. James. 2008. Peer review of teaching in Australian higher education: resources to support institutions in developing and embedding effective policies and practices. Centre for the Study of Higher Education, University of Melbourne. http://www.cshe.unimelb.edu.au/pdfs/PeerReview_FinalReport_forALTC_08.pdf.

Her Majesty’s Stationery Office. 2007. The Further Education Teachers' Qualifications (England) Regulations 2007. The National Archives.

http://www.legislation.gov.uk/uksi/2007/2264/contents/made.

Institute for Learning (Post Compulsory Education and Training) (2011) What we do. Institute for Learning. http://www.ifl.ac.uk/about-ifl/what-we-do.

Lucas, N. and T. Nasta .2010. State regulation and the professionalisation of further education teachers: a comparison with schools and HE. Journal of Vocational Education \& Training 62, no. 4: 441-454.

Misra, P.K. 2011. VET teachers in Europe: policies, practices and challenges. Journal of Vocational Education \& Training 63, no. 1: 27-45.

Moodie, G. 2009. Australia: the emergence of dual sector universities. In Challenging boundaries. Managing the integration of post-secondary education, ed N. Garrod and B. Macfarlane, 59-76. New York: Routledge, Taylor and Francis. 
Moodie, G. 2010. The quality of teaching in VET - framework. Australian College of Educators. https://austcolled.com.au/sites/default/files/VET__Framework_with_Logo_0.pdf.

National Academy of Education. 2009. Teacher quality. An education policy white paper. http://www.naeducation.org/Teacher_Quality_White_Paper.pdf.

Nasta, T. A. 2009. The knowledge that you do every day - easing the transition of those who enter teaching from vocational backgrounds. University of London Institute of Education. http://www.loncett.org.uk/uploads/documents/doc_286.pdf.

NCVER (National Centre for Vocational Education Research). 2009. Australian vocational education and training statistics: employers' use and views of the VET system 2009. http://www.ncver.edu.au/statistic/21066.html.

OECD. 2010. Learning for jobs - the OECD policy review of vocational education and training. Organisation for Economic Co-operation and Development. http://www.oecd.org/document/16/0,3343,en_2649_39263238_45926672_1_1_1_1,00. html\#2.

OECD. 2011, Building a high-quality teaching profession lessons from around the world, Paris, <http://www2.ed.gov/about/inits/ed/internationaled/background.pdf> viewed 21 March 2011

Ofsted. 2003. The initial training of further education teachers: a survey. Ofsted. http://www.ofsted.gov.uk/resources/initial-training-of-further-education-teachers-2003.

Osterman, P. 2011. The promise, performance and policies of community colleges. In Reinventing higher education: the promise of innovation, ed. B. Wildavsky, A.P. Kelly and K. Carey, 129-158. Cambridge, Massachusetts: Harvard Education Press.

Papier, J. 2010. From policy to curriculum in South African vocational teacher education: a comparative perspective. Journal of Vocational Education \& Training 62, no. 2: $153-162$.

Schofield, K. 1999a. Independent investigation into the quality of training in Queensland's traineeship system: report, Queensland, Dept of Employment, Training and Industrial Relations.

Schofield, K. 1999b. Risky business: review of the quality of Tasmania's traineeship system, Hobart, Office of Vocational Education and Training.

Schofield, K. 2000. Delivering quality: report of the independent review of the quality of training in Victoria's apprenticeship and traineeship system, Melbourne, Communications Division, Department of Education, Employment and Training (Victoria). 
Shulman, L. S. 1986. Those who understand: knowledge growth in teaching. Educational Researcher 15, no. 2: 4-14.

Skills Australia. 2011. Skills for Prosperity - a roadmap for vocational education and training. Skills Australia. http://www.skillsaustralia.gov.au/.

Skills Commission (2010) Teacher training in vocational education. Skills Commission. http://www.policyconnect.org.uk/fckimages/skills_report.PDF.

Smith, E., R. Brennan Kemmis, L. Grace and W. Payne. 2009. The new deal: workforce development for service industries VET practitioners. Service Skills Australia. http://www.serviceskills.com.au/dmdocuments/projects/new\%20deal/wfd_full_report.p df.

Training Accreditation Council Western Australia (2010) National strategic industry audit TAA40104 Certificate IV in Training and Assessment final report. http://www.tac.wa.gov.au/Thinking_of_registering/Directory_Publications\#N

Trow, M. 1974. Problems in the transition from elite to mass higher education. In Policies for higher education, Organisation for Economic Co-operation and Development (OECD). Paris: OECD.

Wheelahan, L. and G. Moodie. 2010. The quality of teaching in VET: options paper. Australian College of Educators. https://austcolled.com.au/announcement/study-qualityteaching-vet.

Wheelahan, L. and E. Curtin. 2010. The quality of teaching in VET: overview. Australian College of Educators. https://austcolled.com.au/sites/default/files/VET_1st_report_with_logo_1.pdf

Wheelahan, L. and G. Moodie. 2011. The quality of teaching in VET: final report and recommendations. Australian College of Educators.

https://austcolled.com.au/sites/default/files/quality_vetteaching_final_report1.pdf.

Wolf, A. 2011. Review of vocational education - the Wolf report. Department for Education, London.

http://www.education.gov.uk/publications/standard/publicationDetail/Page1/DFE00031-2011

Young, M. 2006. FET college teachers: a knowledge-based profession of the future. Perspectives in Education, 24, no. 3: 153-160. 